(1) norden

\title{
GENDER MAINSTREAMING IN THE WORK PERFORMED BY GOVERNMENTAL AUTHORITIES
}

- Results and recommendations from a trans-Nordic study

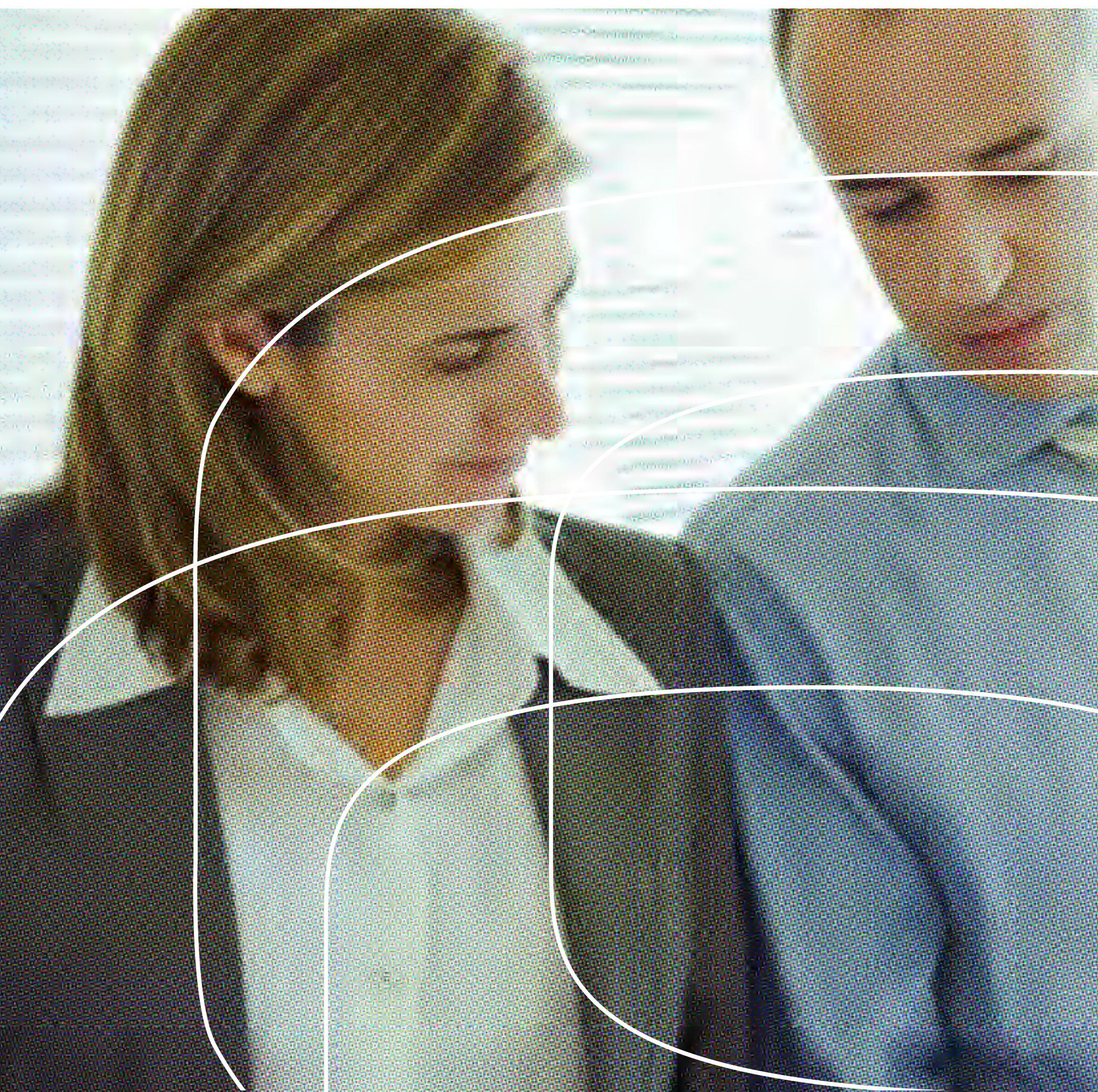


Gender mainstreaming in the work performed by governmental authorities

- Results and recommendations from a trans-Nordic study

ISBN 978-92-893-4097-7 (ISBN)

ISBN 978-92-893-4098-4 (PDF)

http://dx.doi.org/10.6027/ANP2015-748

ANP 2015:748

(C) Nordisk Ministerråd 2015

Layout: Gitte Wejnold

Omslagsfoto: SignElements.com

Foto: SignElements.com

Skrift: Meta LF

www.norden.org/da/publikationer

\section{Nordic co-operation}

Nordic co-operation is one of the world's most extensive forms of regional collaboration, involving Denmark, Finland, Iceland, Norway, Sweden, and the Faroe Islands, Greenland, and Åland.

Nordic co-operation has firm traditions in politics, the economy, and culture. It plays an important role in European and international collaboration, and aims at creating a strong Nordic community in a strong Europe.

Nordic co-operation seeks to safeguard Nordic and regional interests and principles in the global community. Common Nordic values help the region solidify its position as one of the world's most innovative and competitive.

\section{Nordic Council of Ministers}

Ved Stranden 18

DK-1061 Copenhagen $\mathrm{K}$

Telefon (+45) 33960200 


\section{GENDER MAINSTREAMING}

IN THE WORK PERFORMED BY GOVERNMENTAL AUTHORITIES

- Results and recommendations from a trans-Nordic study 


\section{CONTENTS}

GENDER EQUALITY IN A TRANS-NORDIC CONTEXT

BENEFITS OF GENDER MAINSTREAMING

MODEL FOR APPLYING GENDER MAINSTREAMING

RECOMMENDATIONS FOR THE APPLICATION

OF GENDER MAINSTREAMING

1.1.1 Policy on and objectives for gender mainstreaming of core services

1.1.2 Objectives for gender mainstreaming of core services

1.1.3 Tools for application of gender mainstreaming

1.1.4 Results and effects - and documentation thereof 


\section{GENDER EQUALITY \\ IN A TRANS-NORDIC CONTEXT}

\section{WHAT IS GENDER MAINSTREAMING?}

The concept of gender mainstreaming is a method where you incorporate a gender and a gender equality perspective into public administration and planning where gender may be of significance. It is about making policydecisions and preparing core services on an informed basis as well on the basis of the awareness, that gender is a factor that is important in all policy areas.

When gender equality is incorporated into legislation and activities, focus is on whether any differences between genders in a given discipline give rise to special measures or to a need for a different design of measures to reach the relevant target group. It will often be necessary to link gender with other parameters such as education, marital status, ethnicity, age, etc., in order to paint a picture that sufficiently illustrates the target group and thus obtain a basis for targeting measures, etc.

The concept of "ligestillingsvurdering" is used in Denmark. The other Nordic countries apply the concepts of "Integrering av könsperspektiv/ Jämstallhetsintegrering" (Finland), "Kynjasampætting/kønsintegrering" (Island), "Sektoransvar for integrering av kjønnslikestilling” (Norge) og “Jämstallhetsintegrering” (Sweden).
THE NORDIC COUNTRIES are generally characterised by a comprehensive focus on gender equality and have historically had a high degree of equality between women and men as well as girls and boys compared with other countries. This is true in the educational system, the labour market, the political system and society at large. This is also reflected in the fact that the Nordic countries are high up on the "Global Gender Gap Index", where Iceland for example, has been number one for five consecutive years ${ }^{1}$. Even though the Nordic countries rank high in international comparisons of gender equality, it is still important to focus on strengthening gender equality and the application of gender mainstreaming as women and men have different needs and behaviour, which may affect their possibilities of exploiting their resources in full in society and in their daily lives.

This booklet focuses on the results of a study of the use of gender mainstreaming in relation to core services at the central government level across the Nordic countries. The study was launched by the Danish Ministry of Children, Gender Equality, Integration and Social Affairs to obtain knowledge about how the public authorities apply gender mainstreaming on different policy areas, programmes and core services in practice. The study received financial support from the Nordic Council of Ministers. Oxford Research has conducted the study.

The study is based on a questionnaire among the Nordic ministries and studies of 11 good practice 


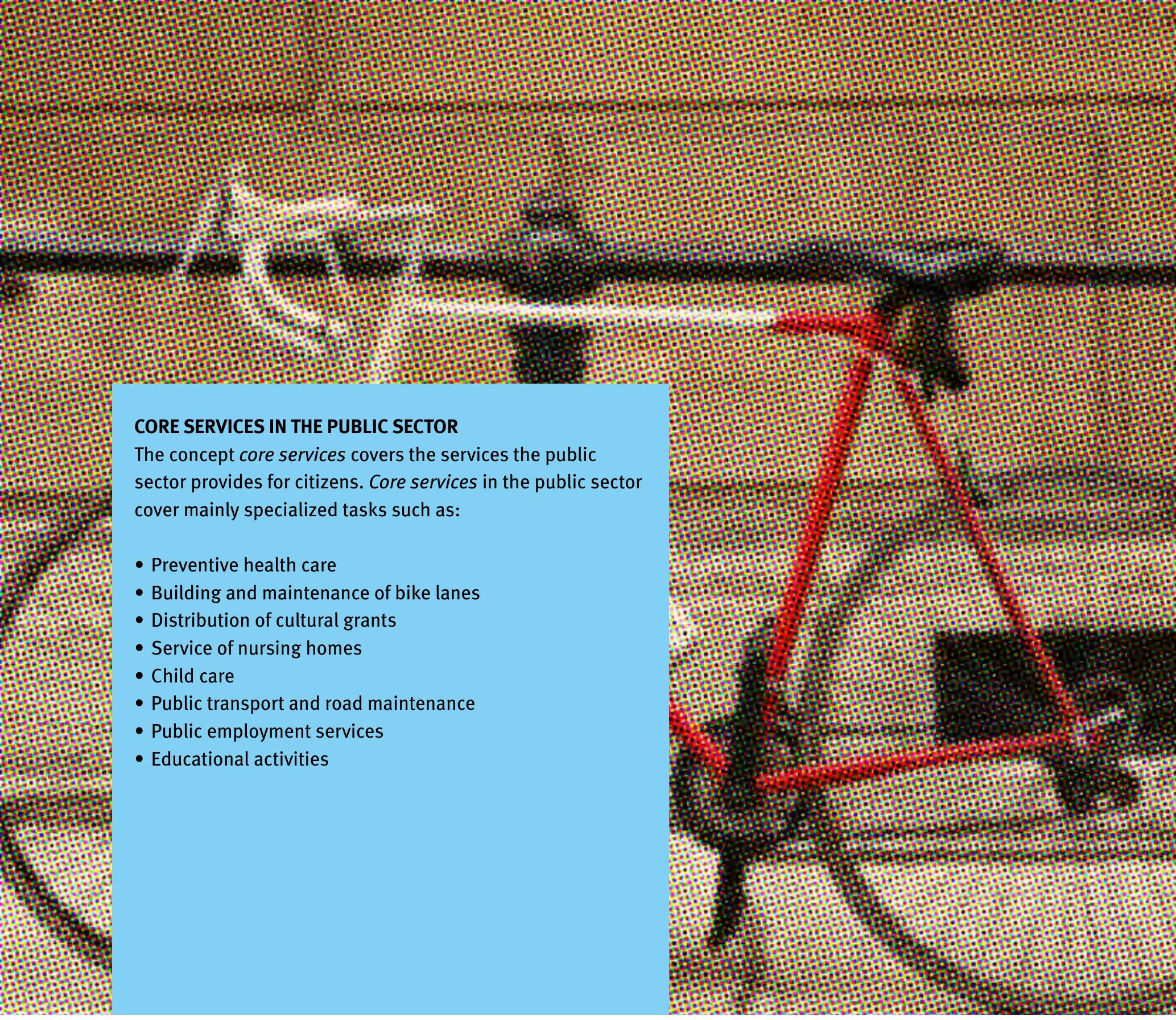

- Preventive health care

Building and maintenance of bike lanes

Distribution of cultural grants

- Service of nursing homes

- Child care

- Public transport and road maintenance

- Public employment services

- Educational activities

examples of gender mainstreaming of central government core services $^{2}$. In this context, core services cover bills, programmes, measures and campaigns. The focus is on how the gender perspective can be incorporated into the core services by applying the gender mainstreaming method as well as what results and effects this might have. On this basis, recommendations and inspiration are provided for how public authorities can best work with gender mainstreaming. The objective is to inspire decision- makers as well as practitians to boost focus on gender equality and gender mainstreaming of central government core services.

The booklet first provides a description of what the concept of gender mainstreaming means ${ }^{3}$ Next, it describes the benefits that the central government can achieve by conducting gender mainstreaming as demonstrated by the results of the study. Then, a model is presented for gender equality work, which can be applied to achieve optimum results from the use of gender mainstreaming, and finally, the booklet provides examples of gender mainstreaming of core services as well as recommendations for how to approach this work.

\footnotetext{
${ }^{1}$ The World Economic Forum, 2013, The Global Gender Gap Report 2013

${ }^{2}$ See more under Further information.

${ }^{3}$ In all Nordic countries gender mainstreaming is defined according to the Council of Europe's definition of gender main-streaming, see http://www.coe.int/t/ $\mathrm{dghl} /$ standardsetting/equality/03themes/gendermainstreaming/index_en.asp
} 


\section{BENEFITS OF GENDER MAINSTREAMING}

The study shows that governmental authorities can achieve results in the form of increased core service quality and equal opportunities for citizens, which has an effect in the form of increased gender equality if they conduct gender mainstreaming in connection with their work.

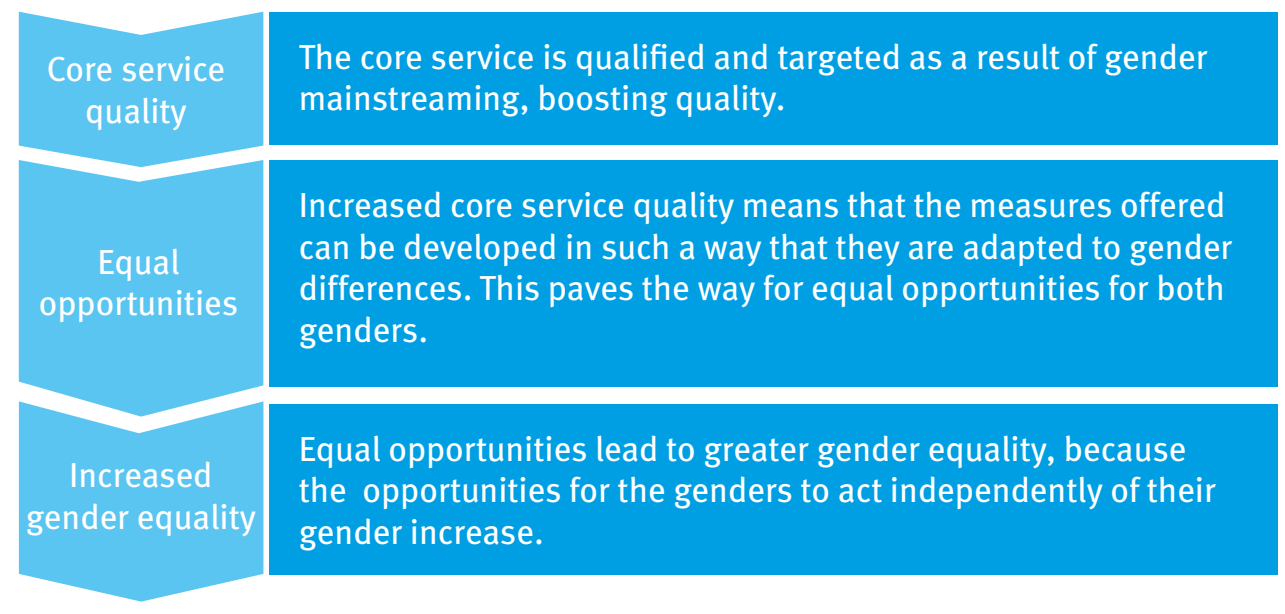

As with all other measures, it is necessary to take into consideration what resources and the extent of such resources that are allocated for applying gender mainstreaming. Resources can take the form of earmarked financial resources, man hours or external sparring for example. The study shows that it is possible to generate results based on both a limited and a significant use of resources, be they financial resources, man hours or external sparring. It is, however, essential to match expectations of benefits and the degree of allocated resources. 



\section{MODEL FOR APPLYING GENDER MAINSTREAMING}

A model for gender mainstreaming has been prepared on the basis of the study of good practice examples. The model shows how different steps in the application of gender mainstreaming are related and mutually influence each other.

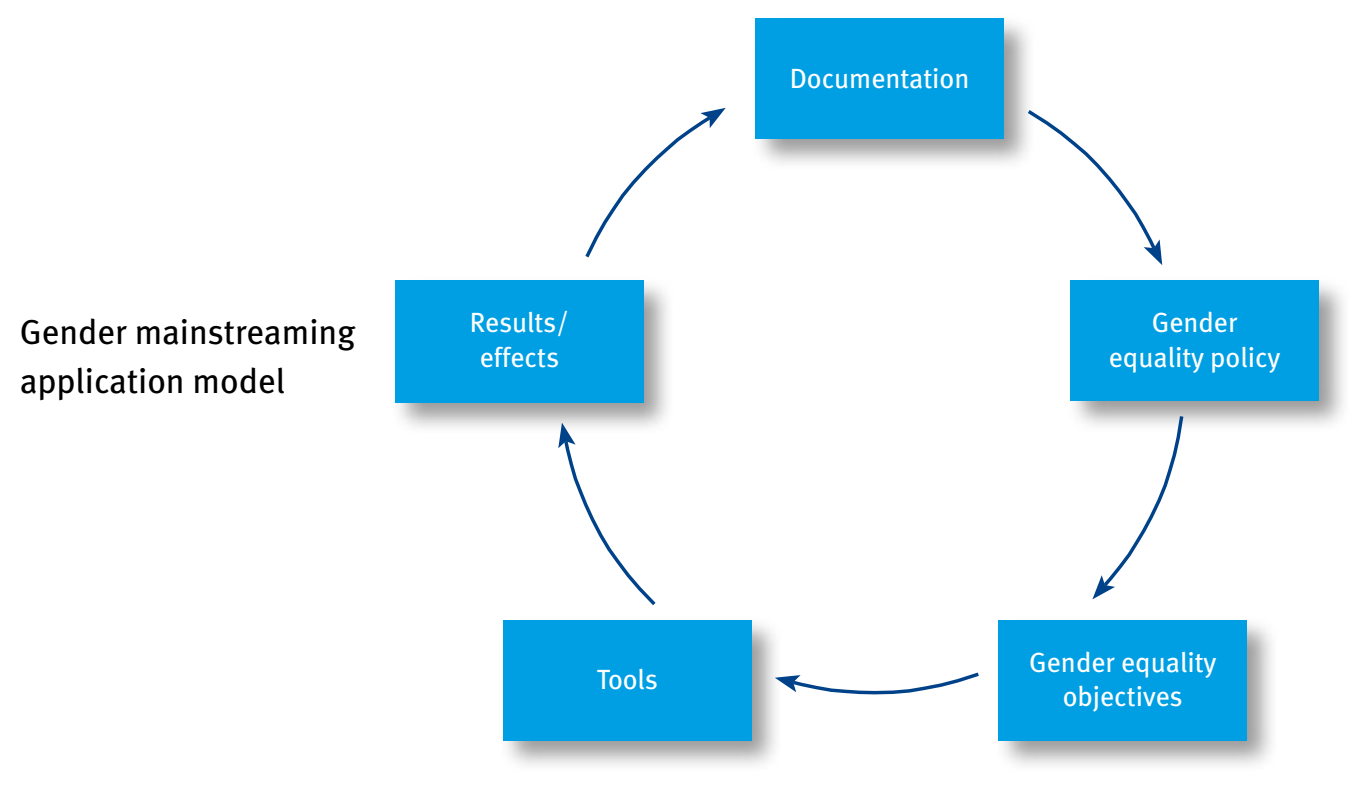

The first step in gender mainstreaming is the use of documentation in the form of gender-segregated data. Data can be based either on quantitative or qualitative studies. Such data is used for performing a gender analysis. In a gender analysis, data is analysed in relation to whether differences exist between the conditions, situations and needs of men/boys and women/girls that have to be taken into consideration in the development of measures, bills, campaigns, etc. Gender can be of importance in cases where this is not visible or obvious and it is therefore essential to perform gender analyses to achieve highquality measures.

Documentation of gender differences, if any, should be used for drawing up policies so that the policies in a given area can be prepared on a well-documented basis.

Once policies have been drawn up, it is easier to formulate specific objectives. Setting specific objectives and establishing measurable indicators for these are essential to address gender and gender equality in the various initiatives. Objectives create the conditions for being able to target the measures and having an effect for the relevant people. Moreover, they are also a condition for being able to measure and draw conclusions in regards to the results and effects of gender mainstreaming and to document these results and effects.

The fourth step in the model is tools. The development and use of tools are essential for ensuring 


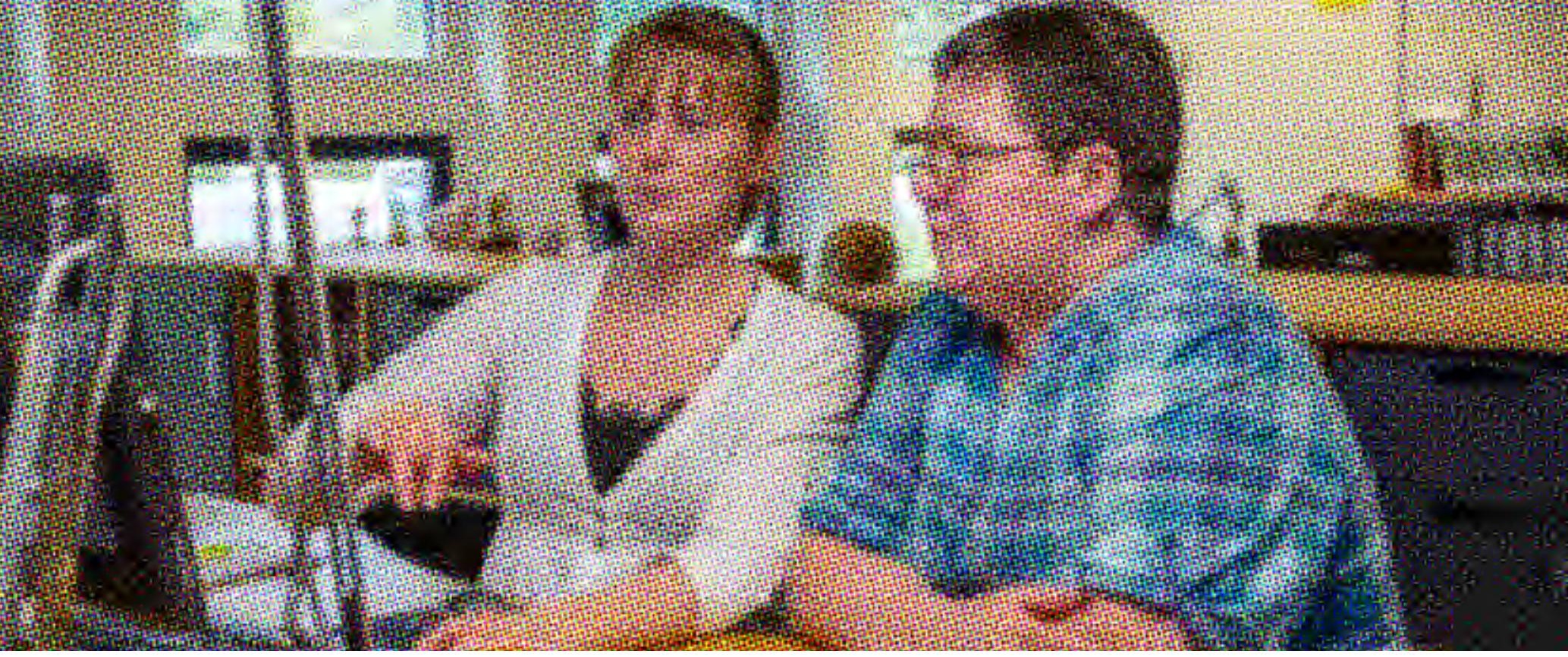

\section{The model can be used to achieve optimum results from the application of gender mainstreaming.}

that managers and employees of public authorities have the required competences to conduct gender mainstreaming. Tools cover gender equality and training in applying gender mainstreaming, procedures for the implementation of gender mainstreaming and concrete tools for these purposes.

The fifth step is results and effects. To be able to generate results in relation to the core service (increased quality) and effects on gender equality of a given measure, the previous steps in the model must have been completed. This means that gender equality policies have been drawn up, that objectives and indicators have been prepared and that managers and employees of public authorities have the necessary tools and competences to conduct gender mainstreaming. If these elements are present and the process is adhered to, the ministries and agencies will, according to the study, achieve results in relation to the core service and effects on gender equality.
The last step of the model is (again) documentation as it is paramount that the achieved results and effects of a given measure are documented so that, for instance, gendersegregated data are generated that can actively be used for gender analyses in connection with the launch of new initiatives.

By following the gender mainstreaming model, public authorities will be able to achieve results in the form of in-creased core service quality and increased gender equality. 


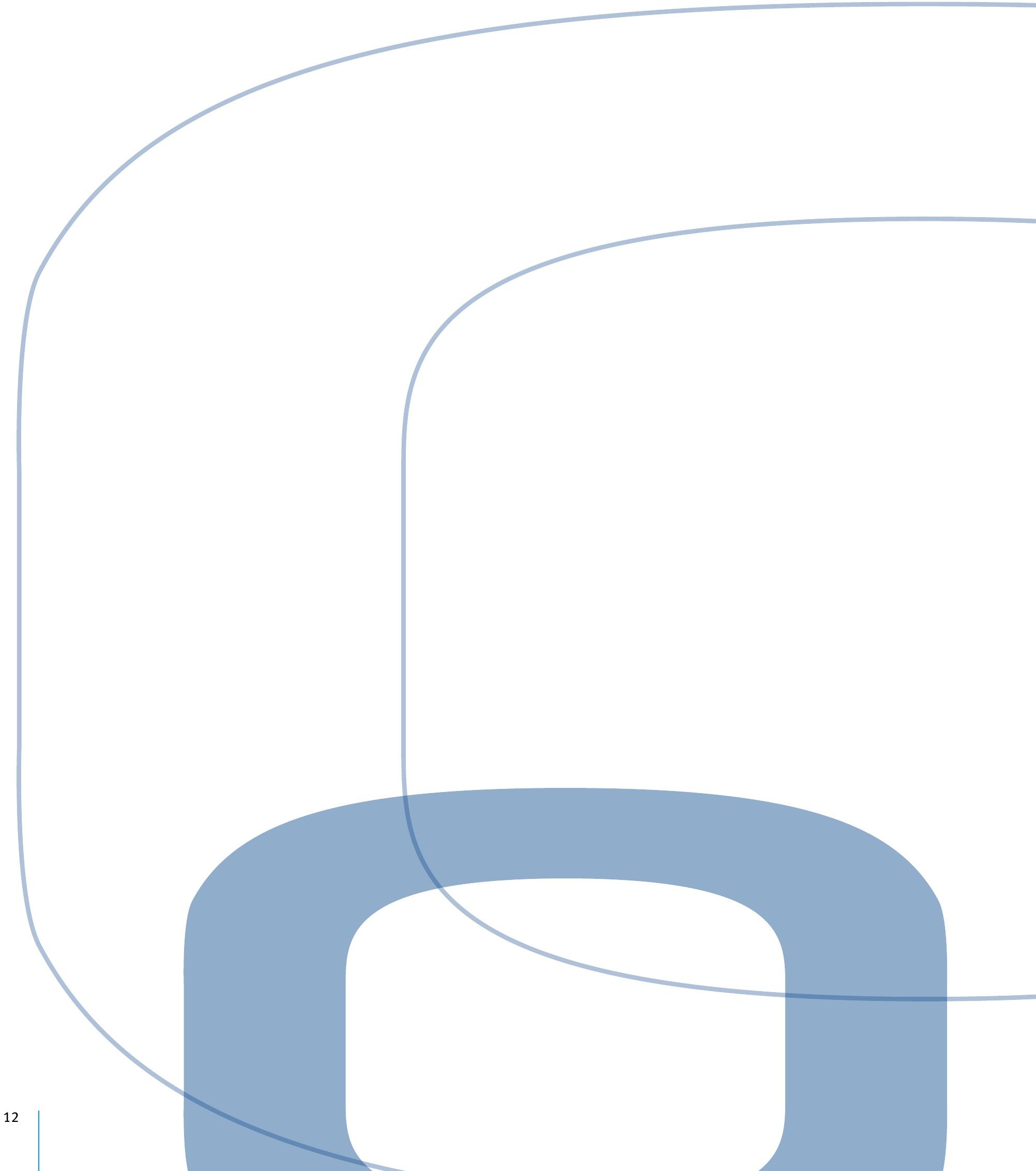




\section{RECOMMENDATIONS FOR THE APPLICATION OF GENDER MAINSTREAMING}

The following section presents recommendations and concrete examples of gender mainstreaming based on the model for applying gender mainstreaming. The recommendations and concrete examples are derived from analysis of the study. The concrete examples are therefore good practice examples of how various public authorities conduct gender mainstreaming. 


\subsection{1 \\ POLICY ON AND OBJECTIVES FOR GENDER MAINSTREAMING OF CORE SERVICES}

A policy prepared for a given policy area or selected areas within that policy area indicates a political focus on gender equality. A policy on gender equality creates increased legitimacy for gender equality as it has been given priority by politicians. Policies create a general framework for the ministries' application of gender mainstreaming, including gender mainstreaming of core services. The political focus on gender equality also means that resources are increasingly being set aside for working with gender equality.

The examples of good practice illustrates how implementation of an overall policy and a specific measure can be approached and what they can contribute to.
Specifically in relation to policies, the recommendations are as follows:

- gender equality policies should be prepared for the various policy areas to establish a general framework for gender equality work and to pave the way for greater legitimacy in regards to gender equality. 


\section{1 .2 \\ OBJECTIVES FOR GENDER \\ MAINSTREAMING OF CORE SERVICES}

In addition to drawing up policies on gender and gender equality, the recommendation is to establish concrete objectives and measurable indicators so that results can be assessed and documented. Objectives can be very concrete, e.g. that the proportion of male childhood educators should be increased by $20 \%$ - which is the case in the following example of good practice. Less concrete objectives can also play the same role as long as measurable indicators for the objective can be established. A measurable indicator of increased gender equality in a kindergarten can, for example, be that more men have applied for admission to the childhood educator programme than in the year earlier or that more men are employed as childhood educators in kindergartens.

The example of good practice shows why setting objectives is important to achieve results of gender equality.
Specifically in relation to objectives, the recommendations are as follows:

- concrete objectives and operational, measurable indicators should be established so that the results and effects of gender equality measures can be measured and conclusions can be drawn. 


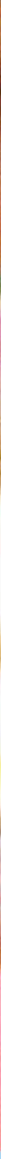

\section{EXAMPLE OF GOOD PRACTICE}

The example Competence enhancement in kindergartens - central government gender equality measures from Norway shows that setting objectives is important to achieve results of gender equality work. One very concrete objective is that the proportion of male childhood educators in kindergartens must be $20 \%$. Another objective is that the learning environment in kindergartens must promote gender equality. This being the case, both concrete and directly measurable objectives as well as more general objectives have been set.

The concrete objective of a proportion of male childhood educators of $20 \%$ means that project results are constantly benchmarked against this objective. Consequently, it is easy to establish whether the objective has been achieved. 


\section{1 .3 \\ TOOLS FOR APPLICATION OF GENDER MAINSTREAMING}

Fixed procedures and tools for gender equality work help develop and embed the practice of gender mainstreaming in the ministries. Procedures and tools make it easier for employees and management to work with gender mainstreaming because they can apply specific instruments and thus obtain help for how to approach the work. In addition, fixed procedures contribute to maintaining focus on gender equality work in the ministries.

But the managers and employees who conduct gender mainstreaming must also have the required competences. This is why it is crucial that both managers and employees are trained in this work - they must be educated/ trained to conduct gender analyses and gender mainstreaming. A step in this process could also be that managers and employees are trained in gender equality to create a common ground and joint understanding of the importance of gender mainstreaming.

Furthermore, gender equality units or internal gender equality advisers (e.g. in the ministries) can promote gender mainstreaming as they, through advisory services, assist in providing public authorities with the necessary competences to conduct gender mainstreaming.

The example of good practice shows what tools a public institution has developed for gender mainstreaming.

In relation to tools for gender mainstreaming, the recommendations are as follows:

- managers and employees applying gender mainstreaming should be trained in gender equality and the preparation of gender mainstreaming of core services, as specific qualifications are called for to work with and apply gender mainstreaming;

- methods, tools and procedures for gender mainstreaming of core services should be prepared and applied as this ensures the embedding of gender mainstreaming in the ministry; and

- relevant gender equality players should be involved actively as advisers in relation to the ministries' gender mainstreaming work. This helps ensure that the ministries have the required competences to apply gender mainstreaming. 


\subsection{4 \\ RESULTS AND EFFECTS \\ - AND DOCUMENTATION THEREOF}

It is essential to provide

documentation to bring to light how

gender mainstreaming influences

the results and effects of a given

measure. In regards to a measure

where gender mainstreaming

has proven that gender is a

relevant factor, it is essential to

document the results and effects

of the measure in relation to

gender equality. In this way, the

results can be used in the future

development of policies, action

plans and concrete measures. The

use of gender-segregated data is

also essential in terms of targeting

initiatives.

When documentation is used as a basis for a given initiative, legitimacy is created in relation to the initiative, because it rests on a well-documented basis. Moreover, legitimacy is also created in relation to increasing incorporation of a gender perspective into the development of initiatives, policies, action plans, etc. It is therefore essential that gender-segregated data are generated on an ongoing basis in terms of behaviour, needs and preferences, as well as the benefits and effects of specific measures that can serve as a platform for future measures.

This example of good practice illustrates how gender-segregated data was used for selecting the target group for a campaign.

In relation to results and effects, the recommendations are as follows:

- gender-segregated data should be compiled. For instance, gender-segregated data could be a requirement in connection with the reporting of results and effects of the work performed by governmental authorities;

- gender-segregated data should be used for preliminary analysis before measures are initiated to ensure that the gender aspect has been incorporated into the measures as that increases core service quality;

- results and effects in relation to greater awareness of gender equality should be documented. This can make visible the fact that measures initiated by the ministries pave the way for greater gender equality and equal opportunities for both genders; and

- the results and effects of applying gender mainstreaming should be rendered more visible and communicated to relevant stakeholders. This applies at several levels, at the political, management and employee level as well as in relation to citizens and stakeholders. Bringing this to light will help muster support for gender mainstreaming. 


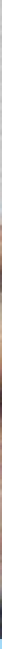

\section{EXAMPLE OF GOOD PRACTICE}

The keyhole label campaign Herrefedt! from Denmark included a gender analysis on the basis of gender-segregated statistics on the health and eating habits of men and women to narrow down and select the target group for the campaign. The campaign targeted men aged 35 and up who were unskilled or had a limited education, as documentation (qualitatively and quantitatively) shows that this group has poorer health than other groups in society and that the target group, to a lesser degree, was aware of the keyhole label.

The campaign aimed to encourage this target group to buy healthier food and make healthier food choices. The campaign was called "Herrefedt!' to capture men's attention, e.g. by means of a brochure with a cover photo of a man's arm holding a large kitchen knife, and dark colours were used, which other studies have shown appeals to men and catches their attention. In addition, a number of events were organised around the country, e.g. with a male chef who cooks using keyhole label products. The campaign team took these approaches because they knew that it was important to reach this group of men and that they are a difficult target group to communicate to.

The campaign is a good example of the considerations underlying a campaign, which is primarily targeted at men and of how the gender aspect has been incorporated into the development of campaign materials and events. Moreover, the campaign is a good example of an initiative targeted at one gender, but where it is ensured that the other gender (in this case women) is not excluded by also incorporating this gender into the development of the campaign material.

Considering the gender of the target group in the preparation of communication materials can help target a given material and thus reach the specific target group of citizens to a higher degree. Thereby, resources are used optimally. Explicit focus on gender equality in communication materials can also help render visible the fact that the authority aims at creating gender equality. 


\section{FURTHER INFORMATION}

For further information about the study and its results (in Danish), reference is made to the report Kortlægning af good practice og effekter i de offentlige myndigheders arbejde med ligestillingsvurdering på udvalgte serviceområder statsligt niveau. The report was drawn up by Oxford Research A/S, September 2014.
The study contains an analysis of governmental authorities' use of gender mainstreaming in the Nordic countries on the basis of

1) a questionnaire among all ministries in the Nordic countries and

2) 11 good practice examples of gender mainstreaming performed by Nordic governmental authorities.
Moreover, the analysis is based on a review of the political, legal, economic and cultural characteristics influencing the application of gender main-streaming in the Nordic countries (national contexts).

\section{DANMARK}

Oxford Research A/S

Falkoner Allé 20

2000 Frederiksberg

Danmark

Tel: (+45) 33691369

office@oxfordresearch.dk
NORGE

Oxford Research AS

Østre Strandgate 1

4610 Kristiansand

Norge

Tel: (+47) 40005793

post@oxford.no
SVERIGE

Oxford Research $A B$

Norrlandsgatan 11

10393 Stockholm

Sverige

Tel: (+46) 08240700

office@oxfordresearch.se
FINLAND

Oxford Research Oy

Helsinki:

Fredrikinkatu 61a, 6krs

00100 Helsinki, Suomi

www.oxfordresearch.fi

office@oxfordresearch.fi
BRUXELLES

Oxford Research

C/o ENSR

5. Rue Archiméde

Box 4, 1000 Brussels www.oxfordresearch.eu office@oxfordresearch.eu 



\section{norden}

Nordic Council of Ministers

Ved Stranden 18

DK-1061 København K

www.norden.org 